The Netherlands

\title{
The Digital Single Market and Legal Certainty: A Critical Analysis
}

Castermans, A.G.; Graaff, R. de; Haentjens, M.; Colombi Ciacchi, A.

\section{Citation}

Castermans, A. G., Graaff, R. de, \& Haentjens, M. (2016). The Digital Single Market and Legal Certainty: A Critical Analysis. In A. Colombi Ciacchi (Ed.), Studies in European Economic Law and Regulation (pp. 45-72). Cham: Springer International Publishing. doi:10.1007/978-3-319-28074-5_5

Version: $\quad$ Publisher's Version

License: $\quad$ Leiden University Non-exclusive license

Downloaded from: https://hdl.handle.net/1887/40563

Note: To cite this publication please use the final published version (if applicable). 


\title{
Chapter 5 \\ The Digital Single Market and Legal \\ Certainty: A Critical Analysis
}

\author{
Alex Geert Castermans, Ruben de Graaff, and Matthias Haentjens
}

\begin{abstract}
This chapter critically examines the CESL from the viewpoint of its capability to provide legal certainty for commercial actors. This chapter's analysis focuses on three important stages in the life cycle of a contract, seen from a business perspective: the scope rules that determine whether the CESL applies to a contract (para. 5.2), the interpretation of entire agreement clauses (para. 5.3) and the legal consequences of a breach of contract (para. 5.4). The chapter concludes that, with a few notable exceptions, the CESL rules do not enable contracting parties to predict, with a sufficient degree of certainty, the legal consequences of entering into the contract. From a business perspective, the CESL rules are therefore not crafted well enough to serve as a blueprint for future legislation.
\end{abstract}

\subsection{The Bundling Career of King Rex}

In his tale about the bundling career of Rex, a fictitious king who wants to reform the law in his country, Lon Fuller distinguishes eight important principles of internal morality. One of them is the duty to adopt clear rules:

The dismay of Rex's subjects was all the more intense, therefore, when his code became available and it was discovered that it was truly a masterpiece of obscurity. Legal experts who studied it declared that there was not a single sentence in it that could be understood either by an ordinary citizen or by a trained lawyer. Indignation became general and soon a picket appeared before the royal palace carrying a sign that read, "How can anybody follow a rule that nobody can understand?"'

The former European Commission was almost as ambitious as the late king Rex. In 2011, it proposed to create a Common European Sales Law (CESL), in order to

\footnotetext{
${ }^{1}$ LL Fuller, The Morality of Law (Revised edition) (New Haven, Yale University Press 1969) 36.

A.G. Castermans $(\square) \bullet$ R. de Graaff $\bullet$ M. Haentjens

Leiden Law School, Institute for Private Law, Leiden, The Netherlands

e-mail: a.g.castermans@law.leidenuniv.nl; r.de.graaff@law.leidenuniv.nl;

m.haentjens@law.leidenuniv.nl
} 
promote and facilitate cross-border trade within the European internal market. ${ }^{2}$ The instrument was to be used in business to consumer ('B2C') and business to business ('B2B') contracts. According to the Commission, parties should be able to choose for 'a single uniform set of contract laws' to govern 'the full life cycle of a contract' . Evidently, the Commission aimed to provide these parties with clear and consistent rules that provide for legal certainty:

This Regulation enables traders to rely on a common set of rules and use the same contract terms for all their cross-border transactions thereby reducing unnecessary costs while providing a high degree of legal certainty. ${ }^{4}$

\section{The European Consumer Organisation BEUC was not convinced:}

This optional tool would increase legal complexity, introduce great legal uncertainty, undermine existing rules on private international law and [sic] as well as consumer protection standards in a number of countries. ${ }^{5}$

What does legal certainty demand, in terms of legislation? In many respects, this is a topical subject. In the Netherlands, it has been given particular attention since the publication of De wet als kunstwerk ('Legislation as a work of art') by the Dutch scholar and senator Willem Witteveen, who died in the MH17 crash before the book was published. ${ }^{6}$ Witteveen adds two commandments to the eight principles of Fuller. He emphasises autonomy and the need for self-regulation, and he stresses that rules should guide behaviour, and not enforce it.

It is also a topical question on the European level. When, by the end of 2014, a new European Commission took office, Better Regulation became one of its priorities. Vice-President Frans Timmermans, who is in charge of this agenda, has repeatedly stated that the EU legislator should focus on the "big issues":

First of all we need to change the attitude that only if I make law am I contributing. There are other ways of contributing without necessarily having to legislate. And this is a cultural thing. We believe we don't exist if we don't make laws.

\footnotetext{
${ }^{2}$ European Commission, Proposal for a Regulation of the European Parliament and of the Council on a Common European Sales Law, Brussels 11.10.2011, COM (2011) 635. Explanatory Memorandum to the Regulation, 4; Art 1 Regulation. This draft Regulation of the European Parliament and of the Council consisted of two parts: Annex I, containing the substantive sales law rules; and the Regulation itself, containing scope rules and other formal provisions. In this chapter, provisions of the Regulation itself will be referred to as CESL Reg., while provisions of the substantive part will be referred to simply as CESL. We will refer to the Commission proposal (COM (2011) 635 final, 2011/0284(COD)), unless indicated otherwise.

${ }^{3}$ European Commission, Proposal for a Regulation of the European Parliament and of the Council on a Common European Sales Law, Brussels 11.10.2011, COM (2011) 635, 16, para 6.

${ }^{4}$ Art 1 (2) CESL Reg (emphasis added).

${ }^{5}$ Joint call by consumers' organisations and e-commerce businesses to reject the Commission's proposal for a Common European Sales Law regulation, letter to EP members, 10 June 2013 (emphasis added). See http://www.fdih.dk/media/1207735/brev_om_cesl_m_beuc_og_ecommerce_europe_juli_2013.pdf

${ }^{6} \mathrm{~W}$ Witteveen, De wet als kunstwerk. Een andere filosofie van het recht (Den Haag, Boom Juridische uitgevers, 2014).

${ }^{7}$ Interview with Vice-President Timmermans, https://euobserver.com/political/127456
} 
On 16 December 2014 the EU Commission presented its Work Programme for 2015 to the European Parliament. The CESL is listed as item 60 in the Annex of withdrawn proposals. ${ }^{8}$ This does not, however, mean that these rules are completely beyond consideration. The Annex states that the proposal is being modified 'in order to fully unleash the potential of e-commerce in the Digital Single Market'. Creating a connected digital single market is indeed one of the top priorities of the Juncker Commission. ${ }^{9}$ One of the aims will be to simplify rules for online digital purchases by consumers. ${ }^{10}$ It is therefore expected that the content of the CESL rules and the amendments proposed by the European Parliament will serve as a blueprint to draft a new instrument, as part of an ambitious digital single market package. ${ }^{11}$

A critical examination of the CESL rules against the commandments of legal certainty is therefore still relevant. But what does legal certainty demand? If we follow Fuller, Van Gerven and Lierman, ${ }^{12}$ and Witteveen, legal certainty demands such rules to be (1) accessible and clear, (2) calculable and reliable, and (3) feasible and enforceable. The first requirement focuses on the content of the rule, which has to be intelligible and clear, in order to enable the legal subject concerned to predict its legal position with a reasonably sufficient degree of certainty and foresee the legal consequences of his decisions. It also concerns the requirement of coherence of the legal order as a whole, and the consistency of its different branches. The second requirement focuses on the durability of legislation: rules may not be altered overnight and changes should be accompanied by a proper law of transitions. The third requirement entails that the legislator takes into account whether the rule is achievable in practical terms: no legal subject should be required to do the impossible, nor should government agencies be held to enforce the unenforceable.

In this chapter, we assume that the CESL rules, if adopted as a part of the digital single market package, will fulfil the second and third requirement. We assume that they will not be changed overnight or without proper arrangements, and that these rules will be applied by the Member States courts and enforceable by the same. In the present context, we wish to measure whether the CESL rules meet the first requirement of accessibility and clarity. Thus, we ask ourselves: are these rules well-crafted or ill-conceived? Do they really enable contracting parties to predict, with a reasonably sufficient degree of certainty, the legal consequences of entering into a CESL contract? We are aware that we should to some extent be cautious, for we recognise that drafting a piece of legislation, especially on the international

\footnotetext{
${ }^{8} \mathrm{http}: / /$ ec.europa.eu/atwork/pdf/cwp_2015_withdrawals_en.pdf

${ }^{9} \mathrm{http} / / /$ ec.europa.eu/atwork/pdf/cwp_2015_new_initiatives_en.pdf

${ }^{10}$ See https://ec.europa.eu/futurium/digital4eu

${ }^{11}$ See the blog by Eric Clive, http://www.epln.law.ed.ac.uk/2015/01/07/proposal-for-a-commoneuropean-sales-law-withdrawn/

${ }^{12} \mathrm{~W}$ van Gerven \& S Lierman, Algemeen Deel. Veertig jaar later (Mechelen, Kluwer, 2010) nr 66: 'Aan de hand daarvan worden hierna beknopt de drie uit het rechtszekerheidsbeginsel voortvloeiende hoofdeisen besproken: (i) toegankelijkheid en duidelijkheid; (ii) berekenbaarheid en betrouwbaarheid; (iii) uitvoerbaarheid en handhaafbaarheid.'
} 
level, is without any doubt a difficult task and sometimes, any legislation (however unclear) may be better than none. No legislation is perfect or immune to criticism. $^{13}$

However, bearing in mind the ambition of the new European Commission to aim for Better Regulation, we do think that it is necessary to hold the CESL rules against the stated objective of 'providing a high degree of certainty', in order to see whether they are fit for further implementation in the future digital single market package. In this chapter, we will not provide a commentary on each and every CESL provision, ${ }^{14}$ or thoroughly compare the CESL with other legal systems. ${ }^{15}$ Instead, we will focus on three important stages in the life cycle of a contract, seen from a business perspective. ${ }^{16}$ After all, the CESL was meant, to a large extent, to serve traders' interests (see Art. 1 (2) CESL Reg. cited above). Moreover, the trader will normally determine the rules of a sales contract and therefore has to be tempted to choose the instrument in the first place. We will examine the scope rules that determined whether CESL applies to a contract (para. 5.2), the interpretation of entire agreement clauses (para. 5.3) and the legal consequences of a breach of contract (para. 5.4).

\subsection{Conclusion, Entering into a CESL Contract}

\subsubsection{General}

As stated above, accessibility and clarity are critical ramifications of legal certainty. This requirement entails that parties to a contract wish to be certain about the rules that apply to the contract they conclude. Consequently: (a) they wish to know the extent of the freedom they have to negotiate the rules applicable to their contract; and, as a corollary of the same, (b) they wish to know which rules of mandatory law will apply. Because the CESL has been proposed as an optional instrument, these issues are particularly acute. Not only does the CESL itself contain rules that are mandatory or semi-mandatory (i.e. parties can agree to derogate from the CESL provided the derogation is not to the detriment of the consumer) and thus may set aside party agreement ${ }^{17}$ but the same agreement may also be set aside by (mandatory rules of) the otherwise applicable, national law, even when the parties have chosen to apply the CESL.

\footnotetext{
${ }^{13} \mathrm{Cf}$. S Vogenauer, 'Drafting and Interpretation of a European Contract Law Instrument', in G Dannemann \& S Vogenauer (eds), The Common European Sales Law in Context (Oxford, OUP, 2013) 83-84.

${ }^{14}$ Eg R Schulze (ed), Common European Sales Law (CESL). A Commentary (Oxford, Hart, 2012). ${ }^{15}$ Eg G Dannemann \& S Vogenauer (eds), The Common European Sales Law in Context: Interactions with English and German Law (Oxford, Oxford University Press, 2013).

${ }^{16}$ For a combined business and consumer perspective: A.G. Castermans, 'Towards a European Contract Law through Social Dialogue', European Review of Contract Law (7) 2011 (360).

${ }^{17}$ Examples of semi-mandatory rules may be found in Arts 69, 71, 75 and 77 CESL, examples of (fully) mandatory rules in Arts 70 and 74 CESL.
} 
In case parties have mistakenly thought that their contract would fall within the CESL's scope, (parts of) the CESL might then apply as a matter of 'incorporation by reference', i.e. the CESL might then apply as if it were clauses agreed by the parties. Yet such clauses cannot preclude mandatory rules of the otherwise applicable national law. Moreover, under Article 6(2) of the Rome I Regulation, ${ }^{18}$ mandatory rules of the consumer's jurisdiction will apply, should this law, in short, protect him better than the (erroneously) chosen CESL rules or the otherwise applicable national law would. ${ }^{19}$ Thus, from a predictability perspective, it is of the utmost importance that parties are sufficiently enabled to determine whether the CESL applies. It is evident that the same predictability is, to a large extent, dependent on clear scope rules. ${ }^{20}$

In this paragraph, we assess whether the CESL scope rules are sufficiently clear. Thus, we assess whether contracting parties, when similar scope rules apply, can predict with a reasonably sufficient degree of certainty whether a court of a European Member State will apply those rules they thought would apply. We will therefore assume that a court in a European Member State will be requested to judge on the application of the CESL rules; that this court has jurisdiction; and that the otherwise applicable, national law will be the law of a Member State, as the proposed CESL could only be chosen as a 'second' law of contract of a Member State. ${ }^{21}$ It will be concluded that contracting parties, most notably the trader, need to make rather complex legal qualifications which, it is submitted, would not have brought certainty in many cases, and will not bring certainty in future cases, if the EU legislature were to adopt a similar approach in its future contract rules for online purchases of digital content and tangible goods.

\subsubsection{Formal Scope Rules}

The scope of the CESL is limited in two ways: both formally and materially. The CESL is limited formally, because it applies only to parties of certain jurisdictions (territorial limitation), only to certain parties (personal limitation), and only when (explicitly) chosen. The CESL is limited materially, because it only applies to certain types of contract.

\footnotetext{
${ }^{18}$ In full: Regulation (EC) No 593/2008 of the European Parliament and of the Council of 17 June 2008 on the law applicable to contractual obligations (Rome I), OJ L 177.

${ }^{19}$ See J Thomas et al. (eds), Statement of the European Law Institute on the Proposal for a Regulation on the Common European Sales Law (ELI, Vienna, 2012) 321 ("ELI Statement"), to be consulted via www.europeanlawinstitute.eu/projects/publications/, 21.

${ }^{20} \mathrm{Cf}$. S Whittaker, 'Identifying the Legal Costs of Operation of the Common European Sales Law', Common Market Law Review 50 (2013) 95.

${ }^{21}$ See Recital (10) CESL. On the ramifications of this policy choice, ie to have CESL function as a 'second' set of contract law rules, rather than, eg, the 28th set of European contract law rules, see, eg, M Fornasier, " 28 " versus "2. Regime" - "Kollisionsrechtliche Aspekte eines optionalen europäischen Vertragsrechts', RabelsZ Bd. 76 (2012) 401 et seq. and M Lehmann, 'Dogmatische Konstruktion der Einwahl in das EU-Kaufrecht (2., 28. oder integriertes Regime) und die praktischen Folgen', in M Gebauer (ed) Gemeinsames Europäisches Kaufrecht - Anwendungsbereich und kollisionsrechtliche Einbettung (2013) 67 et seq.
} 


\subsubsection{Territorial Scope: Cross-Border Requirement}

As a matter of principle, only cross-border contracts are governed by the CESL. ${ }^{22}$ This sounds clear enough, but how would it work out in practice? The CESL distinguishes between business to consumer ('B2C') and business to business ('B2B') cross-border contracts. If the contract is to be $\mathrm{B} 2 \mathrm{C}$, the 'address indicated by the consumer, the delivery address for goods, or the billing address' of the consumer must be located in a different country than the 'habitual residence' of the business, or in the CESL terminology: the trader. ${ }^{23}$ Thus, parties to a contract must first establish whether they qualify as a 'trader' or a 'consumer'.

The 'trader' - 'consumer' qualification must be made on the basis of the definitions of these terms as provided in the CESL Reg. Under Article 2, caput and under (e) the CESL Reg., 'trader' means any natural or legal person who is acting for purposes relating to that person's trade, business, craft, or profession, while under (f), 'consumer' means any natural person who is acting for purposes which are outside that person's trade, business, craft, or profession. ${ }^{24}$

Then, it must be determined where the addresses of both parties are located. The consumer's address (i.e. the address indicated by him, his delivery address, or his billing address) seems straightforward enough. However, it may lead to ambiguity in the following situations: a consumer's habitual residence might lie outside the EU/EEA, while the address indicated by him, the delivery address for goods, or his billing address is inside the EU/EEA. Then, pursuant to Article 6(2) of Rome I Regulation, the mandatory law of the jurisdiction in which his habitual residence lies applies, should this law, in short, protect him better than the CESL would. Thus, even if CESL would (also) apply under Article 4 CESL Reg., then the law of a jurisdiction outside the EU/EEA might also apply if it protects the consumer more. More generally, Article 6(2) Rome I Regulation applies to all transactions of traders with consumers whose habitual residences and addresses lie outside the EU. ${ }^{25}$ In all these cases, a prudent trader would have to investigate whether the law of the consumer's jurisdiction protects the consumer more, which was exactly what the CESL tried to avoid. ${ }^{26}$

\footnotetext{
${ }^{22}$ Recital 13-15, Arts 1(1) and 4 CESL Reg.

${ }^{23}$ Art 4(3) CESL Reg.

${ }^{24}$ Even these definitions are not as straightforward as they might seem, as evidenced by the following Parliament amendment: “(f) 'consumer' means any natural person who is acting for purposes which are outside that person's trade, business, craft, or profession; where the contract is concluded for purposes partly within and partly outside that person's trade and the trade purpose is so limited as not to be predominant in the overall context of the contract, that person shall also be considered to be a consumer; (See the wording of recital 17 of Directive 2011/83/EU)" [emphasis in the original]. This is not to mention the difficulties that arise when one of the parties acts both as a consumer and a trader, or when it is unclear in what capacity the same party is acting. Cf. ECJ 20 January 2005, C-464/01, ECLI:EU:C:2005:32 (Johann Gruber/Bay Wa AG).

${ }^{25}$ See also J Basedow, in M Gebauer (ed) Gemeinsames Europäisches Kaufrecht Anwendungsbereich und kollisionsrechtliche Einbettung (2013) 16.

${ }^{26}$ See Explanatory Memorandum to CESL, 2-4.
} 
The CESL's reference to the trader's address (habitual residence) is even more problematic: it is his 'place of central administration' (siege réel). ${ }^{27}$ However, this rule does not apply if the 'the contract is concluded in the course of the operations of a branch, agency or any other establishment' of the trader. In such instance, that 'branch, agency or any other establishment' should be the relevant location for purposes of CESL (Art. 4(5) CESL Reg.).

As a connecting factor, the trader's siege reel is problematic, as it is not always easy to ascertain where an enterprise's 'place of central administration' is. The Netherlands private international law for instance, does not, as a matter of principle, recognise the place of central administration but rather the place of statutory seat as the connecting factor for, in short, issues of company law (Art. 10:118 Dutch Civil Code (Burgerlijk Wetboek)). Also, the Insolvency Regulation refers, as a matter of principle, to the jurisdiction of a company's 'centre of main interest' (a siege réel rule of sorts), but, presumably to provide certainty, 'the place of the registered office shall be presumed to be the centre of its main interests in the absence of proof to the contrary'. ${ }^{28}$

Even more problematic is the exception for branches: if a 'branch, agency or any other establishment' would be 'the relevant location' for purposes of the CESL, the jurisdiction of that branch, agency or other establishment would be relevant for purposes of establishing whether the cross-border requirement has been met. First, in many instances, it is submitted, it would be virtually impossible to establish whether an 'establishment' would be a 'relevant location'. What to think of all contracts that are to be concluded via internet (which might be the only kind of contracts that the future contract law instrument will apply to): what location would then be 'relevant'? Surely not the location where the trader's IT-equipment is located. ${ }^{29}$ Second, this exception for branches may lead to a possibility of legal arbitrage by multi-national traders, which possibility is not open to SMEs. ${ }^{30}$ Multi-national traders with branches all over Europe may wish to designate branches not located in their consumers' jurisdictions as the 'relevant locations', so that the cross-border requirement will be met and the CESL may apply - when more favourable to the trader. The converse (i.e. that traders designate branches located in their consumers' jurisdictions as the 'relevant locations') might be equally possible, so that the otherwise applicable, national private law must apply, rather than the CESL.

Also, Member States may opt-in and have the CESL apply to all traders with habitual residence in its jurisdiction and to consumers with their addresses in the

\footnotetext{
${ }^{27}$ Art 4(4) CESL Reg.

${ }^{28}$ Art 3(1) Council regulation (EC) No 1346/2000 of 29 May 2000 on insolvency proceedings, OJ L 160 .

${ }^{29} \mathrm{Cf}$. article 4(2)(a) of the Convention on the Law Applicable to Certain Rights in Respect of Securities Held with an Intermediary (concluded 5 July 2006): "For the purposes of paragraph (1) (a), an office is not engaged in a business or other regular activity of maintaining securities accounts [the Convention's connecting factor, the authors] - (a) merely because it is a place where the technology supporting the bookkeeping or data processing for securities accounts is located; (...)."

${ }^{30}$ See also ELI Statement (n 19) 20.
} 
same, and thus forego the cross-border requirement. ${ }^{31}$ This opt-in possibility further complicates matters. Pursuant to the cross-border requirements discussed above, the CESL might not apply. Yet the CESL could nonetheless apply, provided all other CESL Reg. requirements for applicability have been met, and the otherwise applicable law would be the law of a Member State that has opted-in. Consequently, not only must parties investigate per transaction whether the scope rules of the CESL Reg. are met, but also (if the CESL would not apply under its own cross-border requirement) whether the otherwise applicable, national law would be the law of the same Member State as the habitual residence and addresses of the parties, and whether that Member State has opted into CESL under Article 13(a) CESL Reg.

Finally, one of the parties must be located in the EU. This means that in B2B contracts, one of the (two) traders must have his habitual residence in EU, while in B2C contracts, one of the addresses of the consumer must be in the EU. ${ }^{32}$

\subsubsection{Personal Scope: Consumer and SME Requirement}

As stated above, the CESL is limited formally in three ways: it applies only to parties of certain jurisdictions (territorial limitation), only to certain parties (personal limitation), and only when (explicitly) chosen. The personal limitation entails, in short, that the CESL only applies if the buyer is a consumer, or, in case both seller and buyer(s) are traders, one of the parties is a small or medium-sized enterprise ('SME'). ${ }^{33}$

When applying the CESL, parties should therefore not only determine whether the cross-border requirement is met, but also whether this personal requirement is met. To that purpose, parties must - as in the case of the territorial requirement ascertain whether they qualify as a 'trader' or a 'consumer' as defined in the CESL Reg.

In case both parties qualify as 'traders', they would have to ascertain whether one of them qualifies as an SME. For this qualification, Article 7(2) CESL Reg. provides requirements, which - pursuant to Recital (21) - must be interpreted in the light of Commission Recommendation 2003/361. ${ }^{34}$ Consequently, a trader would qualify as an SME if: (i) it employs fewer than 250 employees calculated by Annual Work Units; and (ii) its turnover does not exceed EUR 50 million; or (iii) its balance sheet does not exceed EUR 43 million, calculated according to latest approved accounting period (and, should none be available: according to a bone fide estimate) ${ }^{35}$ Articles $4-6$ of the Annex to Commission Recommendation 2003/361

\footnotetext{
${ }^{31}$ Art 13(a) CESL Reg.

${ }^{32}$ Art 4(3)(b) CESL Reg. and Recital 13.

${ }^{33}$ Art 7(1) CESL Reg.

${ }^{34}$ In full: Commission Recommendation of 6 May 2003 concerning the definition of micro, small and medium-sized enterprises (notified under document number C(2003) 1422), 2003/361/EC, OJ L 124/36.

${ }^{35}$ Art 2(1) of Commission Recommendation 2003/361.
} 
provide further directors for the way to calculate the staff headcount, the financial amounts and reference period. Importantly, these tests must be applied per 'autonomous enterprise', i.e. an enterprise that is not a 'partner enterprise', nor a 'linked enterprise' as defined in Article 3(2) and (3) of the Annex to Commission Recommendation 2003/361 (which definitions fill almost an entire page of the Official Journal).

Thus, this SME test is extremely complex and difficult to establish, especially as regards concerns or group-enterprises. It can be safely assumed that some traders may not wish to investigate or rely on the declaration of their trader counterparty as regards their employee count or turnover/balance sheet numbers. It has even been argued that enterprises themselves nor their advisors often know whether they qualify - at the time of conclusion of a contract - as an SME. ${ }^{36}$ The following scenario would therefore be plausible. Two traders wish to conclude a contract under the CESL. Due to a (considering the varying size of this company perfectly understandable) miscalculation of the headcount of one the parties' companies, they are mistaken in their belief that this party qualifies as an SME. As a result, they are mistaken in their belief that the CESL would apply under its own scope rules. As explained above, under para. 5.2.1., the CESL would then only apply as a matter of 'incorporation by reference', i.e. the CESL might then apply as if it were clauses agreed by the parties. Yet these CESL clauses could be set aside by mandatory rules of the otherwise applicable national law, which neither party has realised nor wished to investigate. In fact: the whole point for the parties in question to choose the CESL to apply was to avoid such time consuming and costly investigation. Consequently, it would be rational for the same enterprises not to rely on a choice for the CESL. ${ }^{37}$

Finally, and similar to the cross-border requirement, Member States may opt-in to have the CESL apply to all traders and thus forego the SME-requirement. ${ }^{38}$ Consequently, parties must investigate per transaction whether the scope rules of the CESL Reg. are met, but also (if the CESL would not apply under its own SME requirement) whether the otherwise applicable, national law would be the law of a Member State that has opted into CESL under Article 13(b) CESL Reg. Other than as regards the cross-border requirement, the otherwise applicable national law need not be the law of the Member State where one of the parties has its habitual residence or address.

\subsubsection{Scope: Requirement of (Explicit) Choice}

The CESL is meant to be an opt-in instrument. This means that the CESL only applies if chosen and agreed by the parties. This agreement to have the CESL apply, i.e. its existence and validity, is governed by the CESL itself. ${ }^{39}$ Again, when analysed more closely from the perspective of a party who wishes the CESL to apply, the

\footnotetext{
${ }^{36}$ Basedow (n 25) 18.

${ }^{37}$ See also ELI Statement (n 19) 13 and 18-19.

${ }^{38}$ Art 13(b) CESL Reg.

${ }^{39}$ Recital (10) and Arts 8-9 CESL Reg.
} 
CESL Reg. provisions on this choice of law agreement are far more complex than one might think at first sight.

Also as regards this choice of law, the CESL distinguishes between agreements made by a trader and consumer on the one hand, and by traders on the other. In case of a B2C contract, the choice to have the CESL apply must meet the following cumulative criteria: (i) the consumer's consent to have the CESL apply must be given in a statement that is separate 'from the statement indicating the agreement to conclude a contract'; (ii) the consumer's consent must be given explicitly; (iii) the trader must have confirmed the same consent; (iv) on a durable medium; and (v) the choice of law must relate to the CESL in its entirety. ${ }^{40}$ It needs no argument that these criteria are rather elaborate, which enhances the risk of non-compliance with one or more of them and thus of non-applicability of the CESL. By contrast, in case of a B2B contract there are no further requirements. ${ }^{41}$

\subsubsection{Material Scope Rules}

As stated above, the CESL is limited formally but also materially, as it applies to certain types of contract only. Thus, parties who wish the CESL to apply must determine whether they and their contract fall within the formal scope of the CESL (as discussed above), and also take the following three steps so as to determine whether their contract falls within the material ambit of the CESL: (i) parties must determine whether their contract concerns a sale of goods, supply of digital content, or related service contract. If not, the CESL cannot apply, at least not with prejudice to mandatory rules of otherwise applicable national law (Art. 5 CESL Reg.); (ii) parties must determine whether no exception applies as defined in Article 6 CESL Reg. Under this provision, the CESL may not apply if the contract is mixedpurpose or contains a form of consumer credit (but only in case of B2C contracts); and (iii) parties must determine whether no exception applies following from the definitions of Article 2 CESL Reg.

Under the definitions of Article 2 CESL Reg., a sale, for instance, can only be governed by the CESL if it leads to a transfer of ownership of goods against a price (Articles 2 caput and under (k), and 1(1) and 3 CESL Reg.). 'Goods' are defined as 'tangible movable items' under Article 2 caput and under (h) CESL Reg., so that electricity, gas, water (unless in limited volume and set quantity) are excluded. However, it is unclear how parties must determine whether the sale leads to a 'transfer of ownership', which may be problematic in cases of retention of title, a fiduciary

\footnotetext{
${ }^{40}$ Arts 8(2) and (3) CESL Reg.

${ }^{41}$ Yet this freedom for traders to 'cherry pick' and choose which parts of CESL to apply seems inconsistent with Art 1 CESL, which implies that mandatory provisions of CESL may not be excluded. Pursuant to an amendment of the European Parliament, traders would not be allowed to escape such mandatory rules. European Parliament Committee on Legal Affairs, Draft Report 2011/0284 (COD) of 18 February 2013 (“EP Draft Report”) 41.
} 
transfer and termination of a provisional transfer of ownership. ${ }^{42}$ This qualification must probably be made under the applicable private international law, as the CESL itself explicitly excludes 'property law including the transfer of ownership'. ${ }^{43}$ Consequently, this exclusion may lead to diverging interpretations of (the scope of) the CESL between Member States.

Finally, the exclusion of mixed contracts may lead to uncertainty. ${ }^{44}$ Even if a minor part of a given contract does not fall under any of the definitions of sale, supply of digital content, or related service contracts as just discussed, then the entire contract falls outside the scope of the CESL and must be deemed governed by the otherwise applicable national law. ${ }^{45}$ Consequently, if a seller grants the buyer deferred payment, the CESL does not apply to the entire contract as such deferred payment qualifies as 'credit', which makes it outside the scope of the CESL under Article 6(1) CESL Reg. It is unclear, however, whether a tax payment policy would also qualify as 'credit' so that CESL would not apply. ${ }^{46}$ It seems safe to assume that this will force traders to make separate contracts, which will add to complexity and therefore to uncertainty, especially if sale and credit would be closely linked (as they are in many cases - think of car sales where financing forms an important part of the sale offer).

\subsubsection{Preliminary Conclusion}

From the above, it follows that the CESL would not have brought legal certainty as advertised as regards its scope rules. ${ }^{47}$ Both the formal scope rules (territorial, personal, choice) and material scope rules have been tested on clarity and predictability. Not only are the scope rules - considered as a set - relatively complex which, by definition, is a form of unclearness and thus may lead to uncertainty, but the rules individually are also difficult to use and in the cases discussed do not lead to unequivocal answers. Some scope rules are extremely difficult to establish: this is the case when parties have to ascertain whether they qualify as an SME. What is more, some scope rules are virtually impossible to establish: this is the case, for instance, when parties have to ascertain what the 'relevant location' of an internet retailer is that has branches all over the EU. Finally, some scope rules require an

\footnotetext{
${ }^{42}$ In its Draft Report, the European Parliament proposes to review the exclusion of retention of title clauses after five years of CESL operation; EP Draft Report (n 40) 21.

${ }^{43}$ Recital (27) CESL.

${ }^{44}$ See ELI Statement (n 19) 21-22. Under the European Parliament proposal, this rule will be abandoned; EP Draft Report ( $\mathrm{n}$ 40) et seq.

${ }^{45}$ See ELI Statement (n 19) 21.

${ }^{46} \mathrm{Cf}$. ELI Statement (n 19) 22.

${ }^{47}$ Accord: S Schaafsma, 'IPR en EPR, Over wisselwerking, eenheidenverscheidenheid' (inaugural lecture Leiden, 2014) 11; and Whittaker (n 19) 108.
} 
investigation into the otherwise applicable law: this is the case when opt-in rules apply and as regards property law matters.

Thus, for the CESL scope rules, its objective of certainty, or, in any event, its objective of not having to establish otherwise applicable law, is not met. In order to enhance their practicability, it is submitted that the scope rules should be individually redrafted, or alternatively, exclusions and refinements should be deleted, as these greatly contribute to the complexity of the current set. ${ }^{48}$ It is foreseeable that the rules will not become clearer if the future instrument will be limited to 'distance contracts', i.e. online purchases of digital content and tangible goods'. This will add yet another limiting scope rule to the already existing ones. ${ }^{49}$

\subsection{The Interpretation of an Entire Agreement Clause}

\subsubsection{General}

Suppose the CESL rules are clearly applicable and a contract has been concluded. One of the main concerns of businesses will then be its interpretation by the courts. How much trust and certainty may they put in their texts? Traditionally, this has been a bone of contention between common law and civil law. Common law emphasises the literal interpretation of the contract, whereas civil law stresses the importance of a more objective interpretation. Although some convergence between civil and common law may be noted since Lord Hoffman famously stated that 'interpretation is the ascertainment of the meaning which the document would convey to a reasonable person', ${ }^{50}$ differences may still exist.

Commercial parties often stress the importance of the wordings of a contract by including a so-called 'entire agreement-'or 'merger clause'. Such a clause states that it is the intention of the parties that the written document contains the entirety of the contract between the parties. The purpose is to preclude a party to rely on a promise or statement, made during the negotiations, when it is not expressly contained in the written document. Does the content of the CESL rules facilitate parties who wish to attain this form of legal certainty?

\footnotetext{
${ }^{48}$ Accord: Basedow (n 24) 21; and H Eidenmüller et al. 'Der Vorschlag für eine Verordnung über ein Gemeinsames Europäisches Kaufrecht', JZ 67 (2012) 288-289.

${ }^{49}$ See the EP Draft Report (n 40) 35 and the Public consultation on contract rules for online purchases of digital content and tangible goods, issued by the European Commission on 12 June 2015, see http://ec.europa.eu/justice/newsroom/contract/opinion/150609_en.htm

${ }^{50}$ Investors Compensation Scheme v. West Bromwich Building Society [1997] UKHL 28; [1998] 1 All ER 98; [1998] 1 WLR 896 (19th June, 1997).
} 


\subsubsection{Interpretation Rules}

Contracts are to be interpreted according to the meaning which a reasonable person would give to them. ${ }^{51}$ The common intention of the parties should in any case be of paramount importance, even if this differs from the normal meaning of the expressions used in the contract. ${ }^{52}$ Specific intentions of one party are relevant if at the time of the conclusion of the contract the other party was aware, or could be expected to have been aware, of such intentions. ${ }^{53}$ Article 59 CESL adds that regard may be had to various facts and circumstances. Although the 'nature and purpose of the contract' is mentioned, ${ }^{54}$ a preference for literal interpretation in business-tobusiness relationships is not evident from Article 59 CESL.

To be certain, parties could agree that there are no other obligations than those stated in the contract. For one, the CESL does not forbid to exclude the application of its interpretation rules in commercial contracts. ${ }^{55}$ Article 72 CESL is devoted to such an entire agreement- or merger clause:

1. Where a contract in writing includes a term stating that the document contains all contract terms (a merger clause), any prior statements, undertakings or agreements which are not contained in the document do not form part of the contract.

2. Unless the contract otherwise provides, a merger clause does not prevent the parties' prior statements from being used to interpret the contract. ${ }^{56}$

These paragraphs do not deserve a beauty prize. They may lead to a situation in which statements, commitments, and arrangements that have not been included in the written contact are not part of the contract (para. 1), while nevertheless prior statements may be taken into account when interpreting the contract (para. 2). Thus, apparently, these statements, taken separately, cannot serve as a ground for any contractual obligation. Yet they may be used to substantiate a line of reasoning. This could be confusing if the line of reasoning results in an interpretation that favours prior statements over the wordings of the contract. Was this the real intention of the parties? This proves that businesses do themselves a great service by also - explicitly ${ }^{57}$ - excluding the use of such statements, even when they have

\footnotetext{
${ }^{51}$ Art 58 (3) CESL.

${ }^{52}$ Art 58 (1) CESL.

${ }^{53}$ Art 58 (2) CESL.

${ }^{54} \mathrm{Art} 59$ (g) CESL.

${ }^{55}$ In consumer contracts, however, (ie contracts in which one of the parties qualifies as a 'consumer', see also above, under para 2.2.1-2.2.2.) such an exclusion is disallowed (Art 64(2) CESL).

${ }^{56}$ The meaning of a merger clause in a consumer sale will be limited, since Article 72(3) provides that the consumer is not bound to such a clause and Article 72(4) forbids the parties to derogate from that rule. Hence, an agreed merger clause will only bind the professional party and is therefore not expected to be used in practice. About this in a critical sense EM Kieninger in Schulze et al. (eds), Common European Sales Law (CESL) - Commentary (Baden-Baden, Nomos, 2012) 353.

${ }^{57}$ Cf. Schulze et al. (eds), Common European Sales Law (CESL) - Commentary (Baden-Baden, Nomos, 2012) 308 and 353.
} 
included an entire agreement clause in their contract. Nonetheless, in spite of its somewhat ambiguous wordings, the CESL facilitates parties that wish to create legal certainty by using entire agreement- or merger clauses.

Yet, one caveat is necessary. One should bear in mind that an entire agreementor merger clause needs to be interpreted itself. Take for example the Lundiformcase, in which the Dutch Supreme Court took a firm stand on what such a clause is all about. ${ }^{58}$ The clause read:

9.1. This Agreement constitutes the entire agreement between the parties and supersedes any earlier written or oral arrangements and agreements made between the parties. (...)

9.5. No variation of this agreement shall be valid unless it is in writing and signed by or on behalf of each of the parties.

The Dutch Supreme Court noted in general terms, after having emphasised that such a clause is a relevant circumstance for interpretation:

(...) that an 'entire agreement clause' on itself is not an interpretation provision. The clause has a specific origin and function in the Anglo-American legal sphere, and has not automatically a special meaning according to Dutch law. [T]he clause does not automatically preclude that for the interpretation of the terms in the contract significance is attached to statements made or actions performed in the stage prior to the conclusion of the contract.

With regard to the specific clause in the Lundiform-case, the Supreme Court held that the Court of Appeal should have taken into account the following statements by Lundiform, referring to the way the contract between Lundiform and the other party, Mexx, had been concluded:

(i) that the parties have not negotiated about the written contract, in particular not about the text of [the entire agreement clause],

(ii) that at the conclusion of the contract Lundiform was not assisted by a lawyer, and

(iii) that the model contract had been drawn up by the legal department of Mexx.

Thus, the Supreme Court assumes that the decision not to negotiate a contract with the assistance of a professional lawyer must lead to the conclusion that there was in fact no equal bargaining power between the parties. As a consequence, the reason to attach great importance to the linguistic meaning of the contract would cease to be valid.

While this line of reasoning seems to be similar to paragraph 2 of Article 72, the CESL seems to be more subtle, as it takes into account whether the parties had equal bargaining power during their negotiations:

To the extent that there is an inconsistency, contract terms which have been individually negotiated prevail over those which have not been individually negotiated within the meaning of Article $7 .{ }^{59}$

\footnotetext{
${ }^{58}$ Dutch Supreme Court, 5/03/13, (2013) NJ, 214 (Lundiform/Mexx).

${ }^{59}$ See for similar provisions: Article 5:104 PECL and Article II.-8:104 DCFR. Article 70 Common European Sales Law still adds to this that the supplier of a contract term that has not been individually negotiated (hence read: could not be negotiated) must have drawn the other party's attention to this term.
} 
According to Article 7 (1) CESL, a contract term is not individually negotiated if it has been supplied by one party and the other party has "not been able to influence its content'. So, it is not decisive whether parties have in fact negotiated about a certain provision, but whether they have been able to question its wordings in the first place. This may prove to be a useful criterion in business-to-business relationships. After all, a professional party who is not satisfied by the contract terms should prove that it has not been able to influence their content. We believe this is just, for a contract should serve the parties as their law, including the tradesman who accepts a contractual term because he considers a contract profitable in its entirety.

\subsubsection{Preliminary Conclusion}

The CESL stresses the importance of entire agreement clauses, while it provides for a criterion to assess whether parties could rely on such a clause. Not the absence of negotiations is decisive, but whether parties were able to influence the content of their contract terms. Despite the ambiguous formulation in Article 72 CESL, which implies that prior statements are not part of the contract but may nonetheless be taken into account when interpreting the contract, the CESL interpretation rules facilitate parties that wish to create legal certainty by using entire agreement- or merger clauses. We advise the Commission to consider these rules for its future instrument, in order to enhance the predictability of the contractual arrangements between commercial parties.

\subsection{The Legal Consequences of a Breach of Contract}

\subsubsection{General}

Unfortunately, contracting parties will not always live up to the expectations. During the lifecycle of a contract, their mutual relationship may take a turn for the worse. The buyer was full of anticipation, only to find out that the delivered goods do not match his expectations and even cause losses and distress. The seller trusted that the other party would pay the price soon after delivery, but is now unable to reach his counterparty. When all else fails, ${ }^{60}$ the scheme of remedies, which affects the enforcement of their rights, becomes of crucial importance to the contracting

\footnotetext{
${ }^{60}$ Of course, parties should first try to seek a solution together, through consultation, mediation or alternative dispute resolution. This has the attention of the EU legislator as well, $c f$. Directive 2013/11/EU of the European Parliament and of the Council of 21 May 2013 on alternative dispute resolution for consumer disputes and amending Regulation (EC) No 2006/2004 and Directive 2009/22/EC (Directive on consumer ADR); Directive 2008/52/EC of the European Parliament and of the Council of 21 May 2008 on certain aspects of mediation in civil and commercial matters.
} 
parties. Any prudent contracting party would therefore want to know beforehand the range of available remedies, their hierarchy and the possibilities to dictate otherwise in their contract. As a result, the degree of certainty provided by the remedial system will generally encourage or discourage parties to enter into a contract. ${ }^{61}$

In this context, two issues divide the different European legal systems and therefore deserve closer examination. First, the legal consequences of a breach of contract, and especially the relationship between damages, specific performance and termination (para. 5.4.2). Is the normal and automatic remedy damages or specific performance, and does termination have a subsidiary character? Second, the relationship between contract and tort law (para. 5.4.3). Once a party claims damages, may he choose the most advantageous remedy or is he confined to base his claim on the CESL?

\subsubsection{The Relationship Between Performance, Damages and Termination}

\subsubsection{Background: Different Approaches in Common and Civil Law}

Common law and civil law traditions display great divergences when it comes to the remedies for breach of contract, at least in theory. While damages are the normal and automatic remedy in the common law, ${ }^{62}$ civil law generally aims at performance of the obligations under the contract. ${ }^{63}$ In the United Nations Convention on Contracts for the International Sale of Goods (CISG), the positions were not reconciled. ${ }^{64}$ While the right to require performance was acknowledged, ${ }^{65}$ the question of whether or not to award this remedy was left to the discretion of the national courts. ${ }^{66}$ This result has been criticised, for example by Erauw and Flechtner:

When they approached the topic of remedies, the drafters seem to have abandoned hope of bridging gaps among domestic legal systems, and to have opted instead for incorporating

\footnotetext{
${ }^{61} \mathrm{Cf}$. V Mak, Performance-oriented remedies in European sale of goods law (Oxford, Hart Publishing, 2009) 1.

${ }^{62}$ Cf. Lord Diplock in Photo Production Ltd v Securicor Ltd [1980] AC 827 (HL) 848-9 and Lord Hoffmann in Co-operative Insurance Society Ltd v Argyll Stores (Holdings) Ltd, [1998] AC 1 (HL).

${ }^{63}$ See generally Mak (n 60) and H Sivesand, The Buyer's Remedies for Non-Conforming Goods (München, Sellier, 2005) 29 et seq.

${ }^{64}$ See AH Kastely, 'The Right to Require Performance in International Sales: Towards an International Interpretation of the Vienna Convention', Washington Law Review 63 (1988) 607-610.

${ }^{65}$ Art 46 (1) and 62 CISG.

${ }^{66} \mathrm{Art} 28$ CISG: 'If, in accordance with the provisions of this Convention, one party is entitled to require performance of any obligation by the other party, a court is not bound to enter a judgment for specific performance unless the court would do so under its own law in respect of similar contracts of sale not governed by this Convention.'
} 
more or less intact the different and even contradictory approaches of different legal traditions. (...) The result is not so much a remedies system as a wilful bundling together of diverse elements, offering an aggrieved buyer or seller a diverse smorgasbord of remedy options from which to choose. ${ }^{67}$

On the European level, an agreement was reached by introducing a clear hierarchy of remedies under the Consumer Sales Directive. ${ }^{68}$ Under this Directive, the consumer has to give the seller the chance to cure a lack of conformity. ${ }^{69}$ As a result, the consequences of a breach of contract are not entirely determined by the buyer's choice for one remedy or the other, or purely by the economic interests of the seller. It has been argued that under Dutch law the remedial scheme now has gained an ever more subtle character, which gives the courts more power to intervene when a particular solution is seen as disproportionate..$^{70}$ This trend may be seen in international sales law and even - according to Mak - in the common law, where the courts 'are beginning to show a tendency towards a wider scope for specific performance'. ${ }^{71}$ It is reflected in recital 32 of the proposed CESL as well:

The Common European Sales Law should aim at the preservation of a valid contract whenever possible and appropriate in view of the legitimate interests of the parties.

This development also affects the possibility to use the remedy of termination. This far-reaching 'remedy' releases both parties from their obligations. ${ }^{72}$ That this 'remedy' should be of an exceptional character is reflected both in the common and the civil law traditions. In the common law, termination is only possible if the term which has been broken is a 'condition' of the contract or if the breach is 'fundamental'. Within the civilian tradition, for example in Germany ${ }^{73}$ and the Netherlands, ${ }^{74}$ termination is generally only possible if the other party has been given an additional period of time to remedy the breach. Both solutions emphasise the subsidiary character of termination, which is mirrored on the European and international level,

\footnotetext{
${ }^{67} \mathrm{~J}$ Erauw and HM Flechtner, 'Remedies under the CISG and limits to their uniform character', in P Šarčević and P Volken (eds), The International Sale of Goods Revisited (Alphen aan den Rijn, Kluwer Law International, 2001) 43-44. Cf. Sivesand (n 62) 105-106.

${ }^{68}$ Directive 99/44/EC of the European Parliament and of the Council of 25 May 1999 on certain aspects of the sale of consumer goods and associated guarantees [1999] OJ L 171.

${ }^{69}$ Art 3 Consumer Sales Directive.

${ }^{70}$ See eg, for Dutch private law, JH Nieuwenhuis, 'Vernietigen, ontbinden of aanpassen (I)', WPNR 1995/6164, 23-26; FB Bakels, Ontbinding van wederkerige overeenkomsten (diss. Leiden), (Deventer, Kluwer, 1993); T Hartlief, Ontbinding: over ongedaanmaking, bevrijding en rechterlijke bevoegdheden bij ontbinding wegens wanprestatie (diss. Groningen), (Deventer, Kluwer, 1994); MM Stolp, Ontbinding, schadevergoeding en nakoming : de remedies voor wanprestatie in het licht van de beginselen van subsidiariteit en proportionaliteit (diss. Nijmegen), (Deventer, Kluwer, 2007).

${ }^{71}$ See Mak (2013) 206.

${ }^{72}$ According to Smith, it is therefore not strictly a remedy; see SA Smith, Atiyah's Introduction to the Law of Contract, $6^{\text {th }}$ ed (Oxford, Clarendon Press, 2005) 371.

${ }^{73} \S 323$ (1) BGB. See M Chen-Wishart and U Magnus, 'Termination, Price Reduction, and Damages', in Dannemann and Vogenauer (n 15) 660.

${ }^{74}$ Art 6:265 (2) Dutch Civil Code.
} 
where either a clear hierarchy of remedies has been introduced (Consumer Sales Directive $)^{75}$ or the requirement of 'fundamental' breach has been adopted as a condition for termination (UNIDROIT Principles) ${ }^{76}$ Does the CESL follow this trend?

\subsubsection{The Remedial Scheme in B2B Transactions}

In line with Article 25 of the CISG, the CESL defines the non-performance of an obligation as 'any failure to perform that obligation, whether or not it is excused'. ${ }^{77}$ It is a broad and objective test, which gives the aggrieved party access to the scheme of remedies. ${ }^{78}$ The buyer may require performance, withhold his own performance, terminate the contract, reduce the price and claim damages. For commercial buyers, this does not mean that the remedy termination may be used immediately. Its application is subject to another, familiar threshold: the non-performance has to be 'fundamental' ${ }^{79}$ This is the case if the non-performance 'substantially deprives the other party of what that party was entitled to expect under the contract, unless at the time of conclusion of the contract the non-performing party did not foresee and could not be expected to have foreseen that result', or if 'it is of such a nature as to make it clear that the non-performing party's future performance cannot be relied on'. 80

Furthermore, the commercial buyer's rights to exercise any remedy - except withholding performance - are subject to cure by the seller and subject to examination and notification requirements. ${ }^{81}$ The buyer has to examine the goods, or have them examined, 'within as short a period as is reasonable not exceeding 14 days from the date of delivery of the goods, supply of digital content or provision of related services' ${ }^{82}$ In the event of a lack of conformity, the buyer has to inform the seller within a reasonable time.$^{83}$ Finally, the buyer will lose his right to terminate the contract 'if notice of termination is not given within a reasonable time from when the right arose or the buyer became, or could be expected to have become, aware of the non-performance, whichever is later' ${ }^{84}$ The European Parliament has proposed to fix this period at two months ${ }^{85}$ which will increase the certainty of this rule and follows the example of the Consumer Sales Directive.

\footnotetext{
${ }^{75} \mathrm{Eg}$ Consumer Sales Directive.

${ }^{76} \mathrm{Eg}$ in the UNIDROIT Principles, Art 7.3.1.

${ }^{77}$ Art 87(1) CESL.

${ }^{78}$ Art 106(1) CESL.

${ }^{79}$ Art $114-115,134$ and 136 CESL.

${ }^{80} \mathrm{Art} 87(2)(\mathrm{a})$ and (b) CESL.

${ }^{81}$ Art 106(2)(a)-(b) CESL.

${ }^{82}$ Art 121(1) CESL.

${ }^{83}$ Art 122(1) CESL.

${ }^{84}$ Art 119 CESL.

${ }^{85}$ Amendment 201.
} 
According to Article 178 CESL, '[a]right to enforce performance of an obligation, and any right ancillary to such a right, is subject to prescription by the expiry of a period of time in accordance'. Because the right to terminate the contract can hardly be qualified as a right to enforce performance, it was unclear whether this remedy was subject to prescription. ${ }^{86}$ Fortunately, the European Parliament has proposed to amend Article 178, to make clear that all remedies for non-performance - except withholding performance - are indeed subject to the rules on prescription. ${ }^{87}$ The short period of prescription is two years ${ }^{88}$ the long period of prescription will be ten years (proposal European Commission) or six years (proposal EP).$^{89}$ In the event of a right to damages for personal injuries, this period is thirty years. ${ }^{90}$

In any event, the buyer will lose his rights based on a lack of conformity if he does not notify the seller 'within two years from the time at which the goods were actually handed over to the buyer in accordance with the contract'. ${ }^{91}$ Here, the European Parliament proposed to add that the buyer 'may still reduce the price or claim damages, except for loss of profit, if he has a reasonable excuse for his failure to give the required notice'. ${ }^{92}$ Although this amendment is understandable, it makes an exception to a clear rule of prescription and does therefore not benefit the clarity of that rule. It does, however, point out the subsidiary character of the right to terminate the contract, which is not available when the buyer failed to notify the seller, even if he has a 'reasonable excuse'.

In its remedial scheme for B2B transactions, the CESL follows its own stated objective of preserving a valid contract whenever possible. It introduces a certain hierarchy and makes termination conditional upon the presence of a 'fundamental' non-performance. With one exception, the amendments proposed by the European Parliament further enhance the clarity of the rules on examination and notification duties, and on the loss and prescription of rights.

\subsubsection{The Remedial Scheme in B2C Transactions}

Quite the opposite can be observed for B2C transactions. Here, the CESL employs a highly consumer-friendly regime. First of all, the threshold for termination is not applicable. A new requirement is being introduced:

\footnotetext{
${ }^{86}$ Cf. ELI Statement (n 19) 321.

${ }^{87}$ Amendment 248.

${ }^{88}$ Art 179(1) CESL.

${ }^{89}$ Amendment 249.

${ }^{90}$ Art 179(2) CESL.

${ }^{91}$ Art 122(2) CESL.

${ }^{92}$ Amendment 204.
} 
In a consumer sales contract and a contract for the supply of digital content between a trader and a consumer, where there is a non-performance because the goods do not conform to the contract, the consumer may terminate the contract unless the lack of conformity is insignificant. $^{93}$

This provision significantly lowers the preconditions for termination. It presumes that any non-conformity is significant and shifts the burden to prove otherwise to the seller. ${ }^{94}$ The seller, in his turn, is not helped with any further definitions, guidelines or non-exhaustive lists with examples, which makes it very difficult to predict which lack of conformity is or is not 'insignificant'. Unfortunately, the European Parliament has decided not to propose amendments to this provision.

Furthermore, the proposal states that the buyer's rights are generally not subject to cure by the seller. ${ }^{95}$ Again, this provision significantly lowers the preconditions for termination and abandons the idea of preserving a valid contract as much as possible. Only one exception has now been proposed by the European Parliament, for goods or digital content 'which are manufactured, produced or modified in accordance with the consumer's specifications or which are clearly personalised' ${ }^{96}$ This exception may be welcomed, but it has to be noticed that the burden of proof is still shifted to the seller, while a general acknowledgment of a right to cure is absent. Add to this that the requirements of examination and notification do not apply to $\mathrm{B} 2 \mathrm{C}$ transactions, ${ }^{97}$ and it is clear that these rules are highly consumer-friendly.

It seems that with respect to B2C transactions, the European Commission has not been able to avoid inconsistencies with previous instruments of international sales law. It departs from the agreed hierarchy under the Consumer Sales Directive and returns to the traditional patterns by allowing an almost absolute freedom to choose between the different remedies for non-conformity. These rules benefit the position of the consumer more than they benefit the position of businesses. But that is not the main problem here. The problem is that commercial parties cannot rely on these rules to predict with a reasonably sufficient degree of certainty the legal consequences of a breach of contract. Without prior notification of the nonconformity itself, their contract may easily be terminated, leaving it to the commercial seller to prove that the lack of conformity was in fact insignificant or related to a tailor-made product.

\footnotetext{
${ }^{93}$ Art 114(2) CESL.

${ }^{94} \mathrm{M}$ von Kossak, 'The Remedial System under the Proposed Common European Sales Law (CESL)', European Journal of Commercial Contract Law 1 (2013) 10.

${ }^{95}$ Art 106(3)(a) CESL.

${ }^{96}$ Amendment 192.

${ }^{97}$ Art 106(3)(b) CESL. With the exception of the notification of termination, see Art 119 CESL and Amendment 201.
} 


\subsubsection{The Relationship Between Damages in Contract and Damages in Tort $^{98}$}

\subsubsection{Concurrent Remedies in Contract and Tort}

A breach of contract may also constitute a violation of a right to property or lead to an injury to body or health. ${ }^{99}$ If a party decides to claim damages for such losses, he may be able to do so on the basis of contractual or tortious liability. This may undermine the certainty the EU legislator wants to provide, because the tort law regimes of the Member States will often differ in terms of establishment, scope and prescription of liability - not only between themselves, but also with the CESL or any other future contractual liability regime. A substantive conflict rule is therefore needed to govern the relationship between contract and tort.

Within Europe, two contrasting approaches exist: some legal systems confine the claimant to contract law, others provide him with the opportunity to also invoke tort law. The first route has been chosen by the French Cour de Cassation. Whenever a fault has been committed in the context of the performance of a contract, the liability may only be based on contract law:

Les Art 1382 et suivants sont sans application lorsqu'il s'agit d'une faute commise dans l'exécution d'une obligation résultant d'un contrat. ${ }^{100}$

This principle of non-cumul des responsabilités protects French contract law against the breadth of the principle-based and very casuistic character of French tort law. ${ }^{101}$ German and English private law take the opposite stance: the claimant has the freedom to choose between an action in contract and an action in tort, when both are possible on the same facts. The claimant is not precluded to bring an action in tort when the liability in contract has been barred or exempted:

Er ist insbesondere nicht gehindert, auf die Haftung aus unerlaubter Handlung zurückzugreifen, wenn vertragliche Ansprüche - etwa wegen eingetretener Verjährung oder einer nur sie erfassenden Haftungsfreizeichnung - nicht mehr bestehen. ${ }^{102}$

\footnotetext{
${ }^{98}$ Parts of this section have been previously published in R de Graaff, Something old, something new, something borrowed, something blue? (Leiden/The Hague, Jongbloed, 2014).

${ }^{99} \mathrm{Cf}$. C von Bar and U Drobnig, The Interaction of Contract Law and Tort and Property Law in Europe. A Comparative Study (München, Sellier European Law Publishers, 2004) 190-191.

${ }^{100}$ Cass. 11 January 1922, DP 1922.I.16. Reaffirmed in Cass. $2^{\text {e }}$ civ. 26 May 1992, Bull. Civ. 1992. II.154; Cass. 1 $1^{\mathrm{e}}$ civ. 19 March 2002, CCC 2002/106, nº 00-13971. See Brieskorn 2010, p. 218.

${ }^{101}$ On the (mis)conceptions about the character of French tort law, see JS Borghetti, 'The Culture of Tort Law in France', JETL 3 (2012/2) 158-182.

${ }^{102} \mathrm{BGH}, 24 / 11 / 76, B G H Z 67,362$ et seq, my italics. This is still the doctrine under German law, see T Zerres, Bürgerliches Recht. Eine Einführung in das Zivilrecht und die Gründzuge des Zivilprozessrechts (Heidelberg, Springer, 2009) 314.
} 
The House of Lords eventually followed this line of reasoning. ${ }^{103}$ Lord Goff of Chieveley expressed the ratio decidendi on behalf of the Lords:

[T] he plaintiff, who has available to him concurrent remedies in contract and tort, may choose that remedy which appears to him to be the most advantageous. ${ }^{104}$

The starting point is the freedom of the claimant to choose between the different applicable regimes.

\subsubsection{The Dividing Line Between Contract and Tort}

Both solutions discussed above result in the precedence of one regime over the other. Either tort law is excluded as a matter of principle (non-cumul), or the least advantageous regime is excluded as a result of the claimant's choice (free concurrence). These solutions seem straightforward, but there is one complicating factor: the dividing line between contract and tort is 'by no means as clear as might be imagined'. 105

Modern contract lawyers question whether the division between contractual obligations, resulting wholly from an exchange of promises, and tortious obligations, imposed by the law, is still accurate. Conversely, tort lawyers struggle with certain cases of tortious liability where the parties are in a contractual relationship. ${ }^{106}$ In 1974, Gilmore proclaimed 'the death of contract', stating that contract law 'is being reabsorbed into the mainstream of "tort". ${ }^{107}$ He was supported by Atiyah, who argued that the idea "that tort liabilities are wholly different from contractual liabilities because the latter arise from consensual obligations is not soundly based, either in logic or in history'. ${ }^{108}$ These findings are supported by the fact that one and

\footnotetext{
${ }^{103}$ Earlier - in 1985 - the House of Lords had expressly rejected the application of tort law within a contractual relationship: 'Their Lordships do not believe that there is anything to the advantage of the law's development in searching for a liability in tort where the parties are in a contractual relationship.' See HL, 3/07/85, AC 1985/80 at 107 (Tai Hing Cotton Mill Ltd/Liu Chong Hing Bank), statement Lord Scarman.

${ }^{104}$ HL 25 July 1994, [1995] 2AC 145, at 184 (Henderson/Merrett Syndicates Ltd), my italics. Earlier, the Irish Supreme Court and the Supreme Court of Canada issued similar judgments: IESC, IR 1979/249 (Finlay/Murtagh); SCC, [1986] 31 DLR (4th) 481 (Central Trust Company/ Rafuse). Cf. Ward 2010, p. 23.

${ }^{105} \mathrm{R}$ Zimmermann, The law of obligations: Roman foundations of the civilian tradition (Oxford, Oxford University Press, 1996) 11; and D Howarth, 'The General Conditions of Unlawfulness', in AS Hartkamp et al. (eds), Towards a European Civil Code (Alphen aan den Rijn, Kluwer Law International, 2011) 848.

${ }^{106} \mathrm{Cf}$. S Deakin, A Johnston and B Markesinis, Markesinis and Deakin's Tort Law. Seventh Edition (Oxford, Clarendon Press, 2013) 15.

${ }^{107}$ G Gilmore, The Death of Contract (Columbus, Ohio State University Press, 1974) 87.

${ }^{108} \mathrm{P}$ Atiyah, The Rise and Fall of Freedom of Contract (Oxford, OUP, 1979) 505.
} 
the same legal issue is characterised as belonging to contract law in one country, while it is dealt with by tort law in another country. ${ }^{109}$

Under French law, it is arguably most difficult to cope with this interaction. The principle of non-cumul may force courts to deny a contractual relationship in order to be able to apply tort law. ${ }^{10}$ Yet, some problems have been solved by complementing the obligations arising from a contract with the requirements of equity, customs and the law on the basis of Articles 1134 and 1135 of the French Civil Code. ${ }^{111}$

The principle of free concurrence forces the courts to limit the freedom of the claimant to bring any action he wishes, in order to do justice to the interests of the defendant. ${ }^{112}$ Under German law, an exception is made when 'the application of tort law would (...) frustrate the purpose of a contract law norm'. ${ }^{113}$ As Koch wrote:

Diese Regel [a free choice for the claimant] soll jedoch keinen Bestand haben, wenn, als

Folge konkurrierender Ansprüche, der Zweck einer Vorschrift unterlaufen wird, was insbe-

sondere bei Haftungsmilderungen und Verjährungsfragen relevant ist. ${ }^{114}$

Under English law, the concurrence between contract and tort is 'subject (...) to ascertaining whether the tortious duty is so inconsistent with the applicable contract that, in accordance with ordinary principle, the parties must be taken to have agreed that the tortious remedy is to be limited or excluded'. ${ }^{115}$ In most cases, tort law will therefore not afford greater protection, because a claimant may benefit from its application only in the absence of a limitation or exclusion of liability in the contract. $^{116}$

It has become clear that different legal systems have different reasons for allowing recourse to tort law or not. The possibility to invoke tort law is limited when it goes against the wording of the contract (England) or against statutory law (Germany), or as a matter of principle, because it would risk to open the floodgates of litigation and compensation (France). ${ }^{117}$ What are the implications for the interaction between the CESL and national tort law?

\footnotetext{
${ }^{109} \mathrm{Eg}$ defective products give the consumer a claim in tort in England, while French courts allow an action in contract. See Zimmermann (n 104) 11-12. Cf. Von Bar and Drobnig (n 98) 848.

${ }^{110}$ Cf. Von Bar \& Drobnig (n 98) 40-41.

${ }^{111}$ For France, see MW Hesselink, 'De opmars van de goede trouw in het Franse contractenrecht', WPNR (1994/6154) 694-698.

${ }^{112}$ Cf. JH Nieuwenhuis, 'They still rule us from their graves', WPNR (2009/6693) 3.

${ }^{113}$ Von Bar \& Drobnig (n 98) 201, emphasis added.

${ }^{114}$ D Koch, Produkthaftung: zur Konkurrenz von Kaufrecht und Deliktsrecht (Berlin, Duncker und Humblot, 1995) 227, emphasis added.

${ }^{115}$ HL 25 July 1994, [1995] 2 AC 145, at 184 (Henderson v. Merrett Syndicates Ltd.), my italics. See also Cartwright 2013, p. 51.

${ }^{116}$ Cf. J O’Donovan, Lender Liability (London, Sweet \& Maxwell Ltd, 2005) 197-198.

${ }^{117} \mathrm{Cf}$. W van Gerven \& S Covemaecker, Verbintenissenrecht (Leuven, Acco, 2006) 310.
} 


\title{
5.4.3.3 The Dividing Line Between CESL and National Tort Law
}

As we have seen, the purpose of the European Commission is to create a selfstanding regime of sales law. However, Recital 28 of the Regulation stresses that the CESL should not govern matters 'outside the remits of contract law' and stipulates that ' $[\mathrm{t}] \mathrm{his}$ Regulation should be without prejudice to the Union or national law in relation to any such matters'. ${ }^{118}$ Recital 27 lists some examples:

\begin{abstract}
These issues include legal personality, the invalidity of a contract arising from lack of capacity, illegality or immorality, the determination of the language of the contract, matters of non-discrimination, representation, plurality of debtors and creditors, change of parties including assignment, set-off and merger, property law including the transfer of ownership, intellectual property law and the law of torts. Furthermore, the issue of whether concurrent contractual and non-contractual liability claims can be pursued together falls outside the scope of the Common European Sales Law. ${ }^{119}$
\end{abstract}

This statement is understandable. Efforts to harmonise private law have so far concentrated on contract and consumer law, not on tort law. ${ }^{120}$ The law of torts concerns a different economic and political reality, making it difficult to demonstrate the necessity of EU legislation. ${ }^{121}$ Only one legislative instrument within the area of private law, also a Regulation, ${ }^{122}$ clearly aims to replace the national law of torts with a ground for non-contractual liability at EU level. ${ }^{123}$ Yet it explicitly states that the interpretation of key concepts is left to the applicable system of national private law. ${ }^{124}$

\footnotetext{
${ }^{118}$ Some areas are also mentioned in Recital 28: 'For example, information duties which are imposed for the protection of health and safety or environmental reasons should remain outside the scope of the Common European Sales Law. This Regulation should further be without prejudice to the information requirements of Directive 2006/123/EC of the European Parliament and of the Council of 12 December 2006 on services in the internal market.'

${ }^{119}$ Emphasis added.

${ }^{120}$ Such efforts have only been pursued at an academic level, for example in Book IV of the Draft Common Frame of Reference. Although the Directive on Product Liability creates an "extra" level of liability, it "shall not affect any rights which an injured person may have according to the rules of the law of contractual or non-contractual liability' (Art 13), and therefore it does not harmonise the general law of torts. See Council Directive 85/374/EEC of 25 July 1985 on the approximation of the laws, regulations and administrative provisions of the Member States concerning liability for defective products.

${ }^{121}$ Cf. Howarth (n 104) 848-851.

${ }^{122}$ Regulation (EC) No 1060/2009 of the European Parliament and of the Council of 16 September 2009 on credit rating agencies, amended by Regulation (EU) No 462/2013 of the European Parliament and of the Council of 21 May 2013 and Regulation (EU) No 513/2011 of the European Parliament and of the Council of 11 May 2011.

${ }^{123}$ Art 35 (1) states: 'Where a credit rating agency has committed, intentionally or with gross negligence, any of the infringements listed in Annex III having an impact on a credit rating, an investor or issuer may claim damages from that credit rating agency for damage caused to it due to that infringement.'

${ }^{124}$ See Art 35 (4): “Terms such as "damage", "intention", "gross negligence", "reasonably relied", "due care", "impact", "reasonable" and "proportionate" which are referred to in this Article but are
} 
Although the Regulation stresses that the CESL should not govern matters outside the remits of contract law, this does not mean that there is no overlap between CESL and national tort law. By bringing consequential losses within the scope of the CESL, the European Commission clearly intended to include a core area in which contractual and tortious liability overlap. ${ }^{125}$ An aggrieved party may be entitled to a sum of money 'as compensation for loss, injury or damage', ${ }^{126}$ including 'economic loss and non-economic loss in the form of pain and suffering' ${ }^{127}$ and 'future loss which the debtor could expect to occur'. ${ }^{128}$

When the victim wishes to claim damages for such losses, the question of whether he is allowed to bring an action in tort will be a matter for the applicable national system of private law. When recourse to tort law is allowed, the question remains whether and to what extent this freedom of choice should be limited. Because consequential losses are included within the scope of the CESL, and because 'only the [CESL] shall govern the matters addressed in its rules' ${ }^{129}$ it seems that the CJEU has to provide this answer. In doing so, it will be guided by general principles of EU law. As Wendehorst wrote:

At the end of the day, it should be the ideas of effet-utile on the one hand and of subsidiarity and proportionality on the other that count, ie we have to ask whether the uniformity of results which the CESL (...) seeks to achieve throughout the EU would require the CESL (...) rules to be exclusive in a particular area or whether parallel regimes of an entirely different nature, in particular tort and property, must be tolerated. ${ }^{130}$

This is not an easy task. On the one hand, the Court of Justice will be tempted to provide all the answers by interpretation of the CESL rules and the existing acquis communaitaire. This is important for countries such as France, where the non-cumul principle forces the courts to protect the CESL from the breadth of French tort law

not defined, shall be interpreted and applied in accordance with the applicable national law as determined by the relevant rules of private international law.'

${ }^{125}$ Some authors are very critical of the proposed definitions: 'In placing loss of an economic and non-economic nature, injury, and damage on the same level, the proposed regulation confuses protected interests with heads of damage. (...) It is difficult to escape the conclusion that these provisions need thorough re-drafting.' This has not happened thus far by amendments of the European Parliament. See H Eidenmüller, N Jansen, EM Kieninger, G Wagner and R Zimmermann, 'The Proposal for a Regulation on a Common European Sales Law: Deficits of the Most Recent Textual Layer of European Contract Law', The Edinburgh Law Review 3 (2012) 340. Interestingly, the international counterpart of the CESL - the UN Convention on Contracts for the International Sale of Goods (CISG) - excludes liability for death or personal injury from its scope. See Art 5 CISG.

${ }^{126}$ Art 2 (g) Reg CESL.

${ }^{127}$ Art 2 (c) Reg CESL.

${ }^{128}$ Art 159 (2) CESL.

${ }^{129}$ See Art 11 Reg CESL.

${ }^{130}$ See the comments by Wendehorst in Schulze et al. (eds), Common European Sales Law (CESL) - Commentary (Baden-Baden, Nomos, 2012) 70, emphasis added. Cf. Howarth (n 104) 849 , according to whom the question surrounding harmonisation in this area of law will always be 'whether the degree of anomaly which results from cases crossing the contract-tort divide is sufficient to justify what otherwise would be a violation of the principle of subsidiarity.' 
as much as they are used to protect French contract law from French tort law. In such a situation, all answers have to be given within the remits of contract law.

However, providing such answers may involve a very inventive interpretation of the CESL, which is written as a comprehensive set of contract rules and is silent or at least not explicit on some matters, such as causation. The Court of Justice will be hampered by the very limitations of the CESL itself. When asked to do so, this may be an argument for an English or German court to provide the answers within the remits of national tort law, especially when it concerns sensitive issues on which there is no European consensus. ${ }^{131}$

In any event, the attempt to draw a clear line between the CESL and tort law would have been ill-fated. This does not mean that the CESL rules provide less certainty than national systems of private law do. It does mean that the claim by the European Commission that commercial parties would only have to acquaint themselves with one common set of rules was untrue. Also with regard to a future instrument of contract law, these parties have to bear in mind that such an instrument will not provide all the answers, that claimants will try to escape into tort law and that national courts follow different approaches in this respect.

\subsection{General Conclusion}

In this chapter, we have measured the CESL rules against the stated objective of providing a high degree of legal certainty through a common set of rules. In doing so, we have taken a business perspective. We have assessed the rules governing three important stages in the life cycle of a contract: the rules that determine whether CESL applies to a contract, the interpretation of entire agreement clauses and the relationship between the different remedies for breach of contract. We have examined whether these rules are clear and predictable.

With regard to the first stage - formal and material scope rules - we conclude that the CESL would not have brought legal certainty as advertised. ${ }^{132}$ Some scope rules are extremely difficult to establish: this is the case when parties have to ascertain whether they qualify as an SME. What is more, some scope rules are virtually impossible to establish: this is the case, for instance, when parties have to ascertain what the 'relevant location' of an internet retailer is that has branches all over the EU. Finally, some scope rules require an investigation into the otherwise applicable law: this is the case when opt-in rules apply and as regards property law matters. It is foreseeable that the rules will not become clearer if the future instrument will be limited to 'distance contracts', i.e. 'online purchases of digital content and tangible goods'. This will add yet another limiting scope rule to the already existing ones.

\footnotetext{
${ }^{131}$ Such as the derogation from a prescription period, or liability in solidum of producers/sellers.

${ }^{132}$ See above, para 5.2.
} 
With regard to the second stage, the CESL rules stress the importance of entire agreement clauses, while they provide for a criterion to assess whether parties could rely on such a clause. Not the absence of negotiations is decisive, but whether parties were able to influence the content of their contract terms. Despite the ambiguous formulation in Article 72 CESL, which implies that prior statements are not part of the contract but may nonetheless be taken into account when interpreting the contract, the interpretation rules facilitate parties that wish to create legal certainty by using entire agreement- or merger clauses. In all, we believe these rules to be sufficiently clear and advise the Commission to consider these rules for its future instrument, in order to enhance the predictability of the contractual arrangements between commercial parties. ${ }^{133}$

With regard to the final stage - the remedies for breach of contract - a nuanced picture emerges. The CESL remedial scheme in B2B transactions lives up to expectations. It introduces a clear hierarchy and makes termination conditional upon the presence of a 'fundamental' non-performance. ${ }^{134}$ Quite the opposite may be observed in B2C transactions. Here, the Commission chose to depart from the hierarchy under the Consumer Sales Directive and to return to the traditional patterns by awarding the consumer an almost absolute freedom to choose between the different remedies for non-conformity. Whereas these rules may be clear in themselves, we do not think commercial parties can rely on them to predict with a reasonably sufficient degree of certainty the legal consequences of a breach of contract. ${ }^{135}$

Furthermore, if a party decides to claim damages for consequential losses, he may do so on the basis of contractual or tortious liability. This may undermine the certainty an instrument of European contract law wants to provide, because tort law regimes of the Member States often differ in terms of establishment, scope and prescription, not only between themselves, but also with the CESL or any other future European contractual liability regime. Although the European Commission clearly intended to include some issues traditionally belonging to tort law into the scope of the CESL, the attempt to draw a clear line between these two areas will be ill-fated. Parties have to bear in mind that a future instrument of contract law will not provide all the answers, that claimants will try to escape into tort law and that national courts follow different approaches in this respect. Any prudent commercial party will therefore have to consider non-contractual liability claims. ${ }^{136}$

In our opinion, the overall conclusion must be that the proposed CESL rules do not live up to the expectations. With a few notable exceptions, they do not enable contracting parties to predict, with a sufficient degree of certainty, the legal consequences of entering into the (CESL) contract. From a business perspective, the current CESL rules are not crafted well enough to serve as a blueprint for future legislation.

\footnotetext{
${ }^{133}$ See above, para 5.3.

${ }^{134}$ See above, para 5.4.2.2.

${ }^{135}$ See above, para 5.4.2.3.

${ }^{136}$ See above, para 5.4.3.3.
} 
It is expected that the CESL rules will be modified and included in a 'digital single market package', which is intended to boost online consumer sales. While drafting this new instrument, we do hope that the EU legislature will take the abovementioned recommendations into account. The Commission already announced its objectives:

The Commission will put forward clear contractual rules for online sales of both physical goods like shoes or furniture and digital content, like e-books or apps. It will fill in the existing legislative gap at EU level regarding digital content and will harmonise a key set of rules for physical goods. This will create a level-playing field for businesses, allow them to take full advantage of the Digital Single Market and sell with confidence across borders. At the same time, it will boost consumer trust in online purchases. Consumers will have even more solid and effective rights. ${ }^{137}$

The Commission is still as ambitious as the late king Rex. Let us hope that no picket will have to appear before the Brussels palace, carrying a sign that reads: "How can anybody follow a rule that nobody can understand?"

\footnotetext{
${ }^{137}$ European Commission, Fact sheet, Who will benefit from a Digital Single Market? 6 May 2015, http://europa.eu/rapid/press-release_MEMO-15-4920_nl.htm
} 